\title{
Reese-Ellsworth Classification Group I
}

National Cancer Institute

\section{Source}

National Cancer Institute. Reese-Ellsworth Classification Group I. NCI Thesaurus. Code C123363.

Very favorable for maintenance of sight. 